\title{
Pengembangan Produk Minuman dari Daging Buah Manggis (Garcinia mangostana L.) Beku
}

\author{
Development of Ready to Drink from Frozen Flesh Mangosteen \\ (Garcinia mangostana L.) Fruit
}

\author{
Fadhilah Nur'Azizah $^{1)}$, Nuri Andarwulan ${ }^{1,2)}$, Sutrisno Koswara ${ }^{1,2)}$ \\ ${ }^{1)}$ Departemen Ilmu dan Teknologi Pangan, Fakultas Teknologi Pertanian, Institut Pertanian Bogor, Bogor \\ ${ }^{2)}$ South East Asian Food and Agricultural Science and Technology Center, Institut Pertanian Bogor, Bogor
}

\begin{abstract}
Mangosteen peel extract is manufactured as nutraceutical with high antioxidant properties. The industry does not process the flesh of the mangosteen fruit yet. The aim of this research was to study the formulation of ready to drink (RTD) mangosteen fruit juice and the stability of its product during storage. The RTD was processed with a hot fill protocol. The organoleptic liking rate of three fruit juice formulas was 5.36 to 5.74 on a scale of 7. The selected formula consisted of fruit pulp and water in the ratio of 1:2.33 or 300:700 g, sugar $70 \mathrm{~g}$, dark red synthetic colorant $0.0680 \mathrm{~g}$, artificial mangosteen flavoring $2.0 \mathrm{~g}$, CMC $0.25 \mathrm{~g}$, ascorbic acid $0.25 \mathrm{~g}$, and sodium benzoate $0.10 \mathrm{gin}$ the total weight of the mangosteen fruit juice of $1000 \mathrm{~g}$. The physicochemical characteristics ( $\mathrm{pH}$, viscosity and total soluble solid) of mangosteen fruit juice decreased during storage. The microbiological characteristic of raw mangosteen pulp and its RTD complied with BSN standard (2014) for fruit juice products.
\end{abstract}

Keywords: formulation, mangosteen fruit juice, ready to drink, storage stability

\begin{abstract}
Abstrak. Ekstrak kulit manggis diproduksi sebagai nutrasetikal antioksidan. Industri penghasilnya belum memproses lebih lanjut daging buah manggisnya. Penelitian ini bertujuan untuk mengolah minuman buah manggis siap minum (RTD) dari buah manggis hasil samping pengolahan ekstrak kulit manggis dan mempelajari stabilitas penyimpanannya. Proses panas yang diterapkan untuk RTD mengikuti metode isi panas. Tingkat kesukaan sensori formula RTD secara keseluruhan dalam kisaran nilai 5.36 sampai 5.74 dari skala 7 (disukai oleh panelis). Perlakuan perbandingan konsentrasi pulp daging buah manggis dan air sebagai formula terpilih adalah 1:2.33 atau 300:700 g, gula $70 \mathrm{~g}$. Bahan tambahan pangan yang digunakan adalah pewarna sintetik merah tua $0.0680 \mathrm{~g}$, mangosteen flavour $2 \mathrm{~g}, \mathrm{CMC} 0.25 \mathrm{~g}$, asam askorbat $0.25 \mathrm{~g}$ dan natrium benzoat $0.10 \mathrm{~g}$ dari total berat jus buah manggis sebesar $1.000 \mathrm{~g}$. Sifat fisikokimia (pH, kekentalan dan TPT) selama satu bulan penyimpanan menurun. Hasil uji pada bahan baku pulp buah manggis dan RTD telah memenuhi standar BSN (2014) untuk minuman buah.
\end{abstract}

Kata Kunci: formulasi, minuman buah manggis, stabilitas penyimpanan

Aplikasi Praktis: Penelitian ini memberikan informasi tentang formulasi minuman buah manggis dan
tingkat kestabilannya selama satu bulan penyimpanan. Hasil penelitian ini menunjukkan potensi
pengembangan usaha di bidang pengolahan minuman buah, khususnya pemanfaatan daging buah manggis
hasil produk samping ekstrak kulit manggis.

\section{PENDAHULUAN}

Manggis disebut sebagai Queen of The Tropical Fruits karena keistimewaan yang dimilikinya. Senyawa bioaktif yang menjadi primadona buah manggis adalah xantone, yaitu senyawa polifenolik sebagai metabolit sekunder yang tidak dipunyai oleh komoditas buahbuahan lainnya (Suvarnakuta et al. 2011). Penelitian Iswari et al. (2006) menunjukkan bahwa komponen seluruh buah manggis yang paling besar adalah kulitnya, yaitu $70-75 \%$, sedangkan daging buahnya hanya $10-15 \%$ dan bijinya $15-20 \%$. Kandungan antioksidan tertinggi terdapat dalam kulit buah manggis, yakni xantone sebesar
$107.76 \mathrm{mg}$ per $100 \mathrm{~g}$ kulit buah. Kulit buah manggis memiliki manfaat sebagai antikanker, pengobatan penyakit jantung, antiinflamasi, antibakteri, dan anti-aging (Pedraza-Chaverri et al. 2008).

Konsumsi buah manggis umumnya disajikan dalam bentuk segar. Pemanfaatan buah manggis sebagai obat tradisional yaitu ekstrak kulit manggis saat ini diproduksi secara komersial oleh industri obat herbal. Namun, perusahaan tersebut tidak mengolah daging atau isi buah manggis dan membuangnya sebagai produk hasil samping yang tidak digunakan. Daging buah manggis tersebut saat ini dibekukan dan dicoba untuk dilakukan penelitian untuk pemanfaatannya. Oleh sebab itu, penelitian

Korespondensi: andarwulan@apps.ipb.ac.id 
ini bertujuan untuk melakukan formulasi minuman buah manggis yaitu produk yang masuk dalam kategori pangan minuman buah (BPOM 2016) siap minum dan mengetahui stabilitas minuman buah manggis siap minum selama satu bulan penyimpanan. Minuman buah manggis diformulasi dari daging buah beku dengan penambahan bahan lainnya dan diproses dengan teknik isi panas.

\section{BAHAN DAN METODE}

\section{Bahan}

Bahan yang digunakan untuk pembuatan minuman buah manggis adalah air minum dalam kemasan, daging buah manggis beku yang diperoleh dari industri ekstrak kulit manggis, gula, perisa artifisial (mangosteen flavor), pewarna sintetik merah tua dan ungu, Carboxy Methyl Cellulose (CMC), asam askorbat dan natrium benzoat. Bahan tambahan untuk formulasi minuman diperoleh dari pasar dan toko kimia/kue di Bogor. Bahan kimia yang digunakan adalah bahan untuk analisis sifat fisikokimia dan mikrobiologi.

Alat yang digunakan untuk membuat produk adalah pulper cum, blender, $\mathrm{pH}$ meter, hand refractometer, Brookfield viscometer, neraca analitik, timbangan buah digital, serta alat-alat pendukung uji organoleptik dan mikrobiologi.

\section{Persiapan bahan baku}

Persiapan bahan dilakukan pada bahan baku berupa daging/isi buah manggis beku. Persiapan bahan baku yang dilakukan yaitu thawing daging buah manggis beku yang masih didalam kemasan plastik polyethylene (PE) 5 kg selama 3 jam dengan air mengalir. Pemisahan daging buah dan biji buah manggis menggunakan alat pulper menghasilkan pulp buah manggis sebesar $3.13 \mathrm{~kg}$. Setelah itu pulp buah manggis dikemas dalam plastik PP $2 \mathrm{~kg}$ dan disimpan dalam freezer hingga proses selanjutnya.

\section{Pemilihan formula minuman buah manggis}

Percobaan formulasi bertujuan untuk menentukan formula dasar dari produk minuman buah manggis. Proses uji coba formulasi produk diawali dengan proses penghancuran pulp dengan blender pada kecepatan 3 selama 1 menit sehingga dihasilkan bubur buah manggis. Bubur buah manggis tersebut disaring dengan saringan plastik dan hasil penyaringannya digunakan sebagai bahan baku. Pada saat uji coba, bubur buah manggis yang digunakan sebanyak $250 \mathrm{~g}$ dan air 750 gram atau setara dengan perbandingan 1:3. Tahap selanjutnya adalah pemasakan bubur buah manggis dengan wadah baskom stainless steel di atas kompor gas.

Penambahan gula, natrium benzoat dan $\mathrm{CMC}$ dilakukan pada suhu pemasakan $60^{\circ} \mathrm{C}$. Jumlah bahan yang ditambahkan antara lain adalah gula sebanyak $70 \mathrm{~g}$, natrium benzoat sebanyak $0.10 \mathrm{~g}$, dan 2 perlakuan CMC, yaitu sebanyak $0.25 \mathrm{~g}$ dan $0.30 \mathrm{~g}$ dari total berat jus buah manggis sebesar $1.000 \mathrm{~g}$. Selama proses pemasakan, dilakukan pengadukan. Pemasakan dilakukan pada suhu $90^{\circ} \mathrm{C}$ selama 5 menit. Selanjutnya, asam askorbat, perisa artifisial dan pewarna sintetik ditambahkan 30 detik setelah proses pemasakan selesai. Jumlah asam askorbat yang ditambahkan sebanyak $0.25 \mathrm{~g}$, perisa artifisial 2.00 $\mathrm{g}$ dan 3 perlakuan penambahan pewarna sintetik merah tua dan ungu dengan perbandingan 0.0388:0.000, 0.0680: 0.0230 dan 0.0680:0.0000 g.

Tahap selanjutnya adalah isi-panas (hot-filling) ke dalam botol PET $250 \mathrm{~mL}$ setelah semua bahan tercampur secara homogen. Proses isi-panas minuman dalam kemasan botol PET dilakukan pada suhu $82-85^{\circ} \mathrm{C}$. Botol PET $250 \mathrm{~mL}$ yang telah disiram air panas $70^{\circ} \mathrm{C}$ dan ditiriskan, selajutnya di diisi dengan sari buah dan ditutup rapat, kemudian ditahan pada kondisi terbalik selama 2-3 menit. Tahap selanjutnya dilakukan proses pendinginan cepat. Pendinginan kemasan diawali dengan perendaman botol dalam air suhu $70^{\circ} \mathrm{C}$ selama 15 detik, lalu dilanjutkan dengan perendaman dalam air dingin. Tahap terakhir adalah pengeringan kemasan botol pada suhu ruang $28^{\circ} \mathrm{C}$. Hasil uji coba terbaik dipilih berdasarkan atribut warna dan rasa produk secara subjektif oleh peneliti. Atribut warna yang dipilih adalah warna merah kulit buah manggis seperti produk minuman buah manggis komersil dan atribut rasa yang dipilih adalah citarasa manis-asam buah manggis segar.

\section{Formulasi minuman buah manggis}

Proses formulasi produk minuman buah manggis sama dengan uji coba formulasi. Ada 5 perlakuan perbandingan konsentrasi pulp buah manggis dan air yaitu $1: 5.67,1: 4.00,1: 3.00,1: 2.33$ dan 1:1.86. Hasil dari 5 formulasi tersebut di uji kekentalannya dan dibandingkan dengan 2 minuman sari buah jambu komersil. Kekentalan minuman sari buah jambu digunakan sebagai acuan karena mempunyai nilai total padatan terlarut yang menjadi target minuman buah manggis yaitu minimum 8.5 ${ }^{\circ}$ Brix (BSN, 2014). Dari ke-5 formula tersebut, diambil 3 formula yang kekentalannya sesuai dengan produk minuman sari buah jambu komersil. Tiga formula minuman buah manggis terpilih dilakukan uji organoleptik dengan parameter warna, rasa, aroma, mouthfeel dan overall. Metode yang digunakan untuk uji organoleptik ini berdasarkan uji rating hedonik menurut BSN 2006. Penerimaan uji organoleptik oleh panelis ditunjukkan menggunakan skala hedonik 1 (sangat tidak suka) sampai 7 (sangat suka). Jumlah panelis yang menilai minuman buah manggis adalah sebanyak 50 orang dengan kategori tidak terlatih. (BSN 2006). Hasil akhir formula minuman buah manggis adalah produk terpilih berdasarkan uji organoleptik.

\section{Stabilitas penyimpanan minuman buah manggis pada suhu $10^{\circ} \mathrm{C}$ dan $28^{\circ} \mathrm{C}$}

Minuman buah manggis terpilih hasil uji organoleptik disimpan pada 2 suhu berbeda, yaitu suhu ruang $\left(28^{\circ} \mathrm{C}\right)$ dan suhu refrigerator $\left(10^{\circ} \mathrm{C}\right)$ selama 28 hari dengan pengamatan dilakukan pada periode penyimpanan $0,7,14,21$, dan 28 hari. Pengamatan dilakukan terhadap nilai $\mathrm{pH}$ ), kekentalan (Brookfield viscometer) 
(BSN 2000) dan total padatan terlarut (TPT) (FSSAI 2012). Penelitian penyimpanan dilakukan dua ulangan.

\section{Uji mikrobiologi Angka Lempeng Total (ALT) dan Angka Kapang Khamir (AKK)}

Uji ALT dan AKK dilakukan untuk mengetahui mutu mikrobiologi bahan baku (pulp buah manggis) dan produk minuman buah manggis siap minum yang disimpan pada 2 suhu penyimpanan (suhu ruang dan refrigerator) selama 5 hari sesuai dengan Bacteriological Analytical Manual (BAM) (2001). Perhitungan dan pencatatan pertumbuhan koloni secara deskriptif berdasarkan Standar Plate Count Agar (CFU/g atau mL).

\section{Analisis data}

Data hasil uji organoleptik, $\mathrm{pH}$, kekentalan dan TPT yang diperoleh dianalisis dengan analisis ragam $\mathrm{One}$-Way ANOVA menggunakan IBM SPSS 22. Uji lanjut Duncan dilakukan untuk mengetahui signifikansi data antar perlakuan.

\section{HASIL DAN PEMBAHASAN}

\section{Pemilihan formula minuman buah manggis}

Pemilihan formula bertujuan untuk memperoleh konsentrasi CMC dan pewarna sintetik terbaik berdasarkan parameter warna dan rasa secara subjektif. Percobaan dilakukan dengan kombinasi penambahan CMC sebesar $0.25 \mathrm{~g}, 0.3 \mathrm{~g}$ dan perbandingan penambahan pewarna sintetik merah tua:ungu 0.039:0.000, 0.068:0.023 dan 0.068:0.000 g dari total dari total berat jus buah manggis sebesar $1.000 \mathrm{~g}$, sehingga terdapat enam formula minuman buah manggis yang dihasilkan.

Pemilihan formula yang dilakukan menggunakan perbandingan konsentrasi pulp dan air sebesar 1:3.00. Berdasarkan pengamatan secara subjektif, formula minuman buah manggis dengan CMC $0.25 \mathrm{~g}$ dan pewarna sintetik merah tua 0.0680 gram dari total dari total berat jus buah manggis sebesar 1000 gram merupakan formula terbaik. Konsentrasi tersebut menghasilkan produk yang stabil, mouthfeel yang tidak terlalu kental, dan warna yang mirip dengan bagian dalam kulit buah manggis.

\section{Formulasi minuman buah manggis}

Karakteristik fisikokimia produk minuman buah manggis. Formulasi minuman buah manggis mengacu pada konsentrasi CMC dan penambahan pewarna sintetik dari hasil pemilihan formula. Dilakukan formulasi produk dengan menggunakan 5 kombinasi perbandingan konsentrasi pulp dan air, yaitu 1:5.67, 1:4.00, 1:3.00, $1: 2.33$ dan 1:1.80. Produk formulasi tersebut diuji kekentalannya dan dibandingkan dengan 2 sampel minuman sari buah jambu komersil. Dua minuman sari buah jambu komersil dengan kekentalan sebesar $60 \mathrm{cP}$ dan 90 cP. Oleh karena itu, 3 formula perbandingan pulp:air terpilih adalah 1:2.33, 1:3.00 dan 1:4.00. Pemilihan 3 formula tersebut disebabkan karena memiliki kekentalan yang menyerupai sari buah jambu komersil.

Kesesuaian produk dalam penggunaan Bahan Tambahan Pangan (BTP) terhadap regulasi BPOM. Berdasarkan data Tabel 1, penggunaan BTP dalam produk minuman buah manggis telah sesuai dengan regulasi BPOM. Carboxy Methyl Cellulose (CMC) dan asam askorbat yang digunakan dalam formulasi sebesar $0.25 \mathrm{~g}$ dari total berat jus buah manggis sebesar $1.000 \mathrm{~g}$ dengan batas maksimum penggunaan Cara Pengolahan Pangan yang Baik (CPPB). Cara Pengolahan Pangan yang Baik (CPPB) dapat diartikan bahwa jumlah BTP yang diizinkan terdapat pada pangan dalam jumlah secukupnya yang diperlukan untuk menghasilkan efek yang diinginkan. Bahan Tambahan Pangan pewarna Karmoisin CI. No. 14720 (Azorubine (carmoisine)), pengawet Natrium benzoat (Sodium benzoate) dan pembawa Propilen glikol (Propylene glycol) yang digunakan dalam formulasi sebesar $68.00 \mathrm{mg}, 100 \mathrm{mg}$ dan $2 \mathrm{~g}$ dari total berat jus buah manggis sebesar $1.000 \mathrm{~g}$ dengan batas maksimum penggunaan berturut-turut sebesar $70 \mathrm{mg} / \mathrm{kg}$, $600 \mathrm{mg} / \mathrm{kg}$ dan $600 \mathrm{mg} / \mathrm{kg}$. BTP pembawa yang diterima oleh peneliti telah diencerkan terlebih dahulu, sehingga penggunaannya lebih banyak. Oleh sebab itu, dapat disimpulkan bahwa bahan tambahan pangan yang digunakan dalam formula minuman buah manggis telah sesuai dengan regulasi BPOM.

Karakteristik organoleptik produk minuman buah manggis. Berdasarkan hasil formulasi minuman buah manggis, perbandingan pulp:air yang terpilih yaitu 1:2.33, 1:3.00 dan 1:4.00. Berdasarkan hasil uji organoleptik, ketiga formula tersebut memiliki nilai rataan hedonik diatas 5 (agak suka) kecuali aroma sebesar 4.74 (netral), tidak ada perbedaan yang nyata pada semua parameter kecuali aroma.

Tabel 1. Kesesuaian produk dalam penggunaan BTP terhadap regulasi BPOM

\begin{tabular}{|c|c|c|c|c|}
\hline $\begin{array}{l}\text { Regulasi } \\
\text { Perka BOM }\end{array}$ & $\begin{array}{l}\text { Hal yang Diatur } \\
\text { dalam Regulasi }\end{array}$ & $\begin{array}{l}\text { Jenis BTP yang } \\
\text { Digunakan }\end{array}$ & $\begin{array}{l}\text { Ukuran Penggunaan BTP dalam Formula dari } \\
\text { Total Berat Jus Buah Manggis Sebesar } 1.000 \mathrm{~g}\end{array}$ & $\begin{array}{c}\text { Batas } \\
\text { Maksimum } \\
(\mathrm{mg} / \mathrm{kg})\end{array}$ \\
\hline $\begin{array}{l}\text { Nomor } 24 \\
\text { tahun } 2013\end{array}$ & BTP penstabil & $\begin{array}{c}\text { Carboxy Methyl Cellulose } \\
\text { (CMC) }\end{array}$ & $0.25 \mathrm{~g}$ & CPPB \\
\hline $\begin{array}{l}\text { Nomor } 06 \\
\text { tahun } 2013\end{array}$ & BTP pembawa & $\begin{array}{l}\text { Propilen glikol } \\
\text { (Propylene glycol) }\end{array}$ & $2.00 \mathrm{~g}$ & 600 \\
\hline $\begin{array}{l}\text { Nomor } 37 \\
\text { tahun } 2013\end{array}$ & BTP pewarna & $\begin{array}{l}\text { Karmoisin Cl. No. } 14720 \\
\text { (Azorubine (carmoisine)) }\end{array}$ & $68.00 \mathrm{mg}$ & 70 \\
\hline $\begin{array}{l}\text { Nomor } 36 \\
\text { tahun } 2013\end{array}$ & BTP pengawet & $\begin{array}{l}\text { Natrium benzoat } \\
\text { (Sodium benzoate) }\end{array}$ & $100.00 \mathrm{mg}$ & 600 \\
\hline $\begin{array}{l}\text { Nomor } 38 \\
\text { tahun } 2013\end{array}$ & BTP antioksidan & $\begin{array}{l}\text { Asam askorbat } \\
\text { (Ascorbic acid) }\end{array}$ & $0.25 \mathrm{~g}$ & CPPB \\
\hline
\end{tabular}

Keterangan: Cara Pengolahan Pangan yang Baik (CPPB) 
Formula dengan perbandingan pulp dan air sebesar 1:2.33 dipilih karena memperoleh nilai rata-rata tertinggi pada semua parameter warna, rasa, aroma, mouthfeel, dan overall. Hasil uji organoleptik rating hedonik terhadap tiga sampel formulasi minuman buah ditunjukkan pada Tabel 2 dan Gambar 1.

Tabel 2. Hasil uji rating hedonik

\begin{tabular}{|c|c|c|c|c|c|}
\hline \multirow{2}{*}{$\begin{array}{c}\text { Formulasi } \\
\text { konsentrasi } \\
\text { pulp buah : } \\
\text { air } \\
\end{array}$} & \multicolumn{5}{|c|}{ Nilai Rataan Hedonik } \\
\hline & Warna & Rasa & Aroma & Mouthfeel & Overall \\
\hline $1: 2.33$ & & & & & \\
\hline & 5.54 & $5.70^{\mathrm{a}}$ & t & a & 5. \\
\hline $1: 4.00$ & $5.52^{\mathrm{a}}$ & $5.40^{\mathrm{a}}$ & $4.74^{\mathrm{b}}$ & $5.30^{\mathrm{a}}$ & $5.36^{a}$ \\
\hline
\end{tabular}

Keterangan: Nilai rata-rata yang diikuti dengan huruf berbeda pada kolom yang sama menunjukkan perbedaan yang nyata $(p<0.05)$

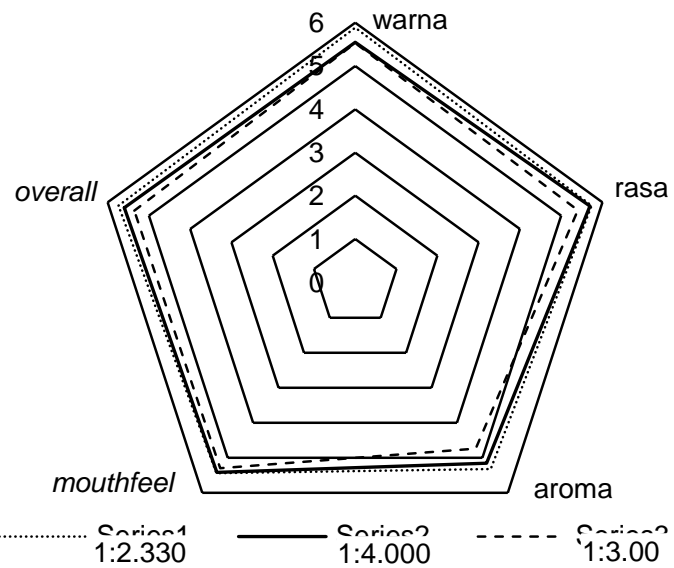

Keterangan: 1 = sangat tidak suka, 2 = tidak suka, 3 = agak tidak suka, 4 = biasa saja, 5 = agak suka, 6 = suka, $7=$ sangat suka

Gambar 1. Grafik radar hasil uji rating hedonik dengan berbagai rasio konsentrasi pulp buah manggis dan air

Perubahan karakteristik fisikokimia minuman buah manggis selama penyimpanan. Minuman buah manggis pada suhu $10^{\circ} \mathrm{C}$ dan $28^{\circ} \mathrm{C}$

Karakteristik fisikokimia (pH, kekentalan dan TPT) dilakukan untuk mengamati kestabilan minuman buah manggis selama penyimpanan. Minuman buah manggis terpilih berdasarkan uji organoleptik adalah formula dengan perbandingan pulp:air sebesar 1:2.33. Pengamatan dilakukan dengan dua perlakuan penyimpanan produk pada suhu refrigerator $\left(10^{\circ} \mathrm{C}\right)$ dan ruang $\left(28^{\circ} \mathrm{C}\right)$ selama hari ke-0, 7, 14, 21, dan 28. Tabel 3, 4 dan 5 menunjukkan perubahan nilai $\mathrm{pH}$, TPT dan kekentalan selama penyimpanan. Data yang dihasilkan terjadi penurunan nilai pada ketiga parameter tersebut. Penurunan nilai $\mathrm{pH}$, TPT dan kekentalan minuman buah menandakan terjadinya pemisahan ikatan antara padatan dengan air seiring berjalannya waktu, sehingga nilai TPT minuman buah manggis mengalami penurunan setelah penyimpanan selama 28 hari pada penyimpanan suhu ruang maupun refrigerator. Hal ini sesuai dengan penelitian Farikha et al. (2013), yaitu nilai pH minuman sari buah naga merah mengalami penurunan seiring dengan lamanya waktu penyimpanan, sehingga mengakibatkan penurunan pada total padatan terlarut (TPT) dan kekentalan produk.
Minuman buah manggis selama penyimpanan pada suhu ruang dan refrigerator, terjadi pemisahan padatan secara visual yang ditunjukkan di Tabel 6, Pemisahan padatan mulai terjadi pada penyimpanan hari ke-14 pada suhu ruang, sedangkan pada penyimpanan suhu refrigerator mulai terjadi pada hari ke-21. Hal ini sejalan dengan penelitian Andriani (2008), yaitu sampel sari buah jeruk yang disimpan pada suhu refrigerator lebih stabil dibandingkan saat disimpan pada suhu ruang. Hal ini juga berhubungan dengan data $\mathrm{pH}$, viskositas dan TPT yang nilainya menurun selama penyimpanan.

Tabel 3. Perubahan nilai pH minuman buah manggis selama penyimpanan

\begin{tabular}{cccccc}
\multicolumn{5}{c}{ Suhu } & \multicolumn{5}{c}{ Nilai Rataan pH pada Hari ke- } \\
\cline { 2 - 6 } Penyimpanan & $\mathbf{0}$ & $\mathbf{7}$ & $\mathbf{1 4}$ & $\mathbf{2 1}$ & $\mathbf{2 8}$ \\
\hline \multirow{2}{*}{$10^{\circ} \mathrm{C}$} & $3.79 \pm$ & $3.78 \pm$ & $3.76 \pm$ & $3.74 \pm$ & $3.75 \pm$ \\
& $0.01^{\mathrm{a}}$ & $0.01^{\mathrm{a}}$ & $0.01^{\mathrm{a}}$ & $0.01^{\mathrm{a}}$ & $0.01^{\mathrm{a}}$ \\
$28^{\circ} \mathrm{C}$ & $3.79 \pm$ & $3.75 \pm$ & $3.72 \pm$ & $3.69 \pm$ & $3.67 \pm$ \\
& $0.01^{\mathrm{a}}$ & $0.00^{\mathrm{b}}$ & $0.00^{\mathrm{a}}$ & $0.00^{\mathrm{b}}$ & $0.01^{\mathrm{b}}$ \\
\hline
\end{tabular}

Keterangan: Nilai rata-rata yang diikuti dengan huruf berbeda pada kolom yang sama menunjukkan perbedaan yang nyata $(p<0.05)$

Tabel 4. Perubahan nilai TPT minuman buah manggis selama penyimpanan

\begin{tabular}{cccccc}
\hline Suhu & \multicolumn{5}{c}{ Nilai TPT $\left({ }^{\circ}\right.$ Brix (\%)) pada Hari ke- } \\
\cline { 2 - 6 } Penyimpanan & $\mathbf{0}$ & $\mathbf{7}$ & $\mathbf{1 4}$ & $\mathbf{2 1}$ & $\mathbf{2 8}$ \\
\hline \multirow{2}{*}{$10^{\circ} \mathrm{C}$} & $11 \pm$ & $10.85 \pm$ & $10.78 \pm$ & $10.62 \pm$ & $10.45 \pm$ \\
& $0.00^{\mathrm{a}}$ & $0.07^{\mathrm{a}}$ & $0.03^{\mathrm{a}}$ & $0.17^{\mathrm{a}}$ & $0.07^{\mathrm{a}}$ \\
$28^{\circ} \mathrm{C}$ & $11 \pm$ & $10.70 \pm$ & $10.55 \pm$ & $10.30 \pm$ & $10.00 \pm$ \\
& $0.00^{\mathrm{a}}$ & $0.00^{\mathrm{a}}$ & $0.00^{\mathrm{a}}$ & $0.00^{\mathrm{a}}$ & $0.01^{\mathrm{b}}$ \\
\hline
\end{tabular}

Keterangan: Nilai rata-rata yang diikuti dengan huruf berbeda pada kolom yang sama menunjukkan perbedaan yang nyata $(p<0.05)$

Tabel 5. Perubahan nilai kekentalan minuman buah manggis selama penyimpanan

\begin{tabular}{cccccc}
\hline Suhu & \multicolumn{5}{c}{ Nilai Kekentalan (cP) pada Hari ke- } \\
\cline { 2 - 6 } Penyimpanan & $\mathbf{0}$ & $\mathbf{7}$ & $\mathbf{1 4}$ & $\mathbf{2 1}$ & $\mathbf{2 8}$ \\
\hline \multirow{2}{*}{$10^{\circ} \mathrm{C}$} & $90.0 \pm$ & $84.5 \pm$ & $81 \pm$ & $79 \pm$ & $76.5 \pm$ \\
& $0.00^{\mathrm{a}}$ & $0.70^{\mathrm{a}}$ & $1.41^{\mathrm{a}}$ & $1.41^{\mathrm{a}}$ & $2.12^{\mathrm{a}}$ \\
$28^{\circ} \mathrm{C}$ & $90.0 \pm$ & $81.0 \pm$ & $75.7 \pm$ & $71 \pm$ & $62.5 \pm$ \\
& $0.00^{\mathrm{a}}$ & $0.14^{\mathrm{a}}$ & $0.07^{\mathrm{b}}$ & $0.14^{\mathrm{b}}$ & $0.00^{\mathrm{b}}$ \\
\hline
\end{tabular}

Keterangan: Nilai rata-rata yang diikuti dengan huruf berbeda pada kolom yang sama menunjukkan perbedaan yang nyata $(p<0.05)$

Tabel 6. Pengamatan produk perbandingan pulp:air 1:2.33 pada penyimpanan suhu refrigerator dan ruang

\begin{tabular}{|c|c|c|}
\hline $\begin{array}{c}\text { Lama } \\
\text { Penyimpanan } \\
\text { Hari ke- }\end{array}$ & $\begin{array}{c}\text { Penyimpanan } \\
\text { Suhu Refrigerator } \\
10^{\circ} \mathrm{C} \\
\end{array}$ & $\begin{array}{c}\text { Penyimpanan } \\
\text { Suhu Ruang } \\
28^{\circ} \mathrm{C} \\
\end{array}$ \\
\hline 0 & - & - \\
\hline 7 & - & - \\
\hline 14 & - & + \\
\hline 21 & + & + \\
\hline 28 & + & + \\
\hline
\end{tabular}

Keterangan: tanda + menunjukkan adanya pemisahan padatan (endapan)

\section{Karakteristik mikrobiologi Angka Lempeng Total (ALT) dan Angka Kapang Khamir (AKK)}

Batasan cemaran mikroba yang ditetapkan dalam BSN (2014) tentang minuman sari buah untuk ALT dan AKK maksimum adalah $1 \times 10^{4} \mathrm{koloni} / \mathrm{mL}$ dan $1 \times 10^{2}$ koloni/mL. Hasil pengujian ALT (Tabel 7) menunjukkan bahwa semua sampel, baik pulp buah manggis maupun minuman buah manggis memenuhi syarat mutu minuman sari buah yang sudah ditetapkan. 
Tabel 7. Hasil angka lempeng total (ALT) dan angka kapang khamir (AKK)

\begin{tabular}{|c|c|c|c|c|c|c|}
\hline Sampel & $\begin{array}{c}\text { Lama } \\
\text { Penyimpanan }\end{array}$ & $\begin{array}{c}\text { Suhu } \\
\text { Penyimpanan }\end{array}$ & $\begin{array}{l}\text { Jumlah Bakteri } \\
\text { (koloni/mL) }\end{array}$ & $\begin{array}{c}\text { Persyaratan } \\
\text { SNI 3719:2014 }\end{array}$ & $\begin{array}{c}\text { Jumlah } \\
\text { Kapang Khamir } \\
\text { (Koloni/mL) }\end{array}$ & $\begin{array}{c}\text { Persyaratan } \\
\text { SNI 3719:2014 }\end{array}$ \\
\hline $\begin{array}{l}\text { Bahan baku pulp } \\
\text { buah manggis }\end{array}$ & 3 minggu & $-18^{\circ} \mathrm{C}$ & $<1 \times 10^{3}\left(0.5 \times 10^{2}\right)$ & maks. $1 \times 10^{5}$ & $1.5 \times 10^{4}$ & maks. $1 \times 10^{2}$ \\
\hline $1: 2.33$ & 5 hari & $10 \stackrel{\circ}{C}$ & $<1 \times 10^{3}$ & maks. $1 \times 10^{4}$ & $<1 \times 10^{2}$ & maks. $1 \times 10^{2}$ \\
\hline $1: 2.33$ & 5 hari & $28^{\circ} \mathrm{C}$ & $<1 \times 10^{3}$ & maks. $1 \times 10^{4}$ & $<1 \times 10^{2}$ & maks. $1 \times 10^{2}$ \\
\hline
\end{tabular}

Namun nilai AKK (Tabel 7) dalam bahan baku pulp buah melebihi batas maksimum yang diperbolehkan, yaitu $1.5 \times 10^{4}$ (> $\left.1 \times 10^{2} \mathrm{koloni} / \mathrm{mL}\right)$. Hal ini diduga disebabkan pulp daging buah manggis hasil pemisahan daging buah dengan biji dari buah manggis beku menggunakan alat pulper yang tidak langsung diproses untuk formulasi minuman buah manggis. Selanjutnya, pulp daging buah manggis yang dibekukan dan kemudian dithawing untuk formulasi inilah yang dianalisis AKK. Proses thawing isi buah manggis lalu pemisahan daging buah dengan isi dan selanjutnya membekukan kembali pulp daging buah meningkatkan nilai AKK. Nilai AKK pulp daging buah manggis yang lebih tinggi dari standar tidak berpengaruh terhadap nilai AKK produk minuman buah manggis. Hal ini menunjukkan bahwa proses panas dengan teknologi isi panas telah memadai. Nilai AKK pada produk minuman buah manggis yang disimpan suhu ruang maupun suhu refrigerator adalah $<1 \times 10^{2}$ koloni/mL, sehingga minuman buah manggis secara mutu layak untuk dikonsumsi. Hasil ini menunjukkan bahwa tahap pengolahan dan penanganan dalam pembuatan minuman buah manggis berkontribusi dalam menjaga mutu produk, yaitu dengan adanya penurunan AKK pada produk akhir apabila dibandingkan dengan AKK pada bahan baku pulp.

\section{KESIMPULAN}

Formula minuman buah manggis terpilih secara organoleptik dengan perbandingan konsentrasi pulp buah manggis dan air sebesar 1:2.33 atau 300:700 g, gula $70 \mathrm{~g}$, penambahan pewarna sintetik merah tua $0.0680 \mathrm{~g}$, mangosteen flavour $2 \mathrm{~g}, \mathrm{CMC} 0.25 \mathrm{~g}$, asam askorbat 0.25 $\mathrm{g}$ dan natrium benzoat $0.10 \mathrm{~g}$ dari total berat jus buah manggis sebesar 1000 g. Nilai pH minuman adalah 3.80 (<4.50), kekentalan $90 \mathrm{cP}$ dan TPT $11^{\circ} \mathrm{Brix}\left(>8.5^{\circ} \mathrm{Brix}\right)$ telah sesuai BSN (2014) untuk minuman sari buah. Minuman buah manggis yang disimpan pada dua suhu penyimpanan mengalami penurunan nilai $\mathrm{pH}$, kekentalan dan TPT. Karakteristik mikrobiologi (ALT dan AKK) minuman buah manggis yang telah disimpan suhu refrigerator dan ruang selama 5 hari memenuhi standar BSN (2014) yaitu $<1 \times 10^{3}$ (maks. 1 x 10 $10^{4}$ ) dan $<1 \times 10^{2}$ (maks. $\left.1 \times 10^{2}\right)$.

\section{UCAPAN TERIMA KASIH}

Terima kasih penulis ucapkan untuk Program Indofood Riset Nugraha dari PT. Indofood Sukses Makmur Tbk. yang telah memberi bantuan dana, pesan moral, arahan serta pengalaman yang tidak terlupakan selama penelitian.

\section{DAFTAR PUSTAKA}

Andriani D. 2008. Formulasi Sari Buah Jeruk Pontianak (Citrus nobilis var. Microcarpa) dengan Aplikasi Metode Lye Peeling sebagai Upaya Penghilangan Rasa Pahit pada Sari Buah Jeruk. [Skripsi]. Bogor: Program Sarjana, Institut Pertanian Bogor.

[BAM] Bacteriological Analytical Manual Online. 2001. Aerobic plate count. Center for Food Safety and Applied Nutrition. USA: U.S. Food and Drug Administration. https://www.fda.gov/food/laboratory-methods-food/bacteriological-analytical-manual-bam\#archive.

[BPOM] Badan Pengawas Obat dan Makanan. 2013a. Peraturan Kepala Badan Pengawas Obat dan Makanan Nomor 6 Tahun 2013 tentang Batas Maksimum Penggunaan Bahan Tambahan Pangan Pembawa. Jakarta: Badan Pengawas Obat dan Makanan.

[BPOM] Badan Pengawas Obat dan Makanan. 2013b. Peraturan Kepala Badan Pengawas Obat dan Makanan Nomor 24 Tahun 2013 tentang Batas Maksimum Penggunaan Bahan Tambahan Pangan Penstabil. Jakarta: Badan Pengawas Obat dan Makanan.

[BPOM] Badan Pengawas Obat dan Makanan. 2013c. Peraturan Kepala Badan Pengawas Obat dan Makanan Nomor 36 Tahun 2013 tentang Batas Maksimum Penggunaan Bahan Tambahan Pangan Pengawet. Jakarta: Badan Pengawas Obat dan Makanan.

[BPOM] Badan Pengawas Obat dan Makanan. 2013d. Peraturan Kepala Badan Pengawas Obat dan Makanan Nomor 37 Tahun 2013 tentang Batas Maksimum Penggunaan Bahan Tambahan Pangan Pewarna. Jakarta: Badan Pengawas Obat dan Makanan.

[BPOM] Badan Pengawas Obat dan Makanan. 2013e. Peraturan Kepala Badan Pengawas Obat dan Makanan Nomor 38 Tahun 2013 tentang Batas Maksimum Penggunaan Bahan Tambahan Pangan Antioksidan. Jakarta: Badan Pengawas Obat dan Makanan.

[BPOM] Badan Pengawas Obat dan Makanan. 2016. Peraturan Kepala Badan Pengawas Obat dan Makanan Nomor 21 Tahun 2016 tentang Kategori Pangan. Jakarta: Badan Pengawas Obat dan Makanan. 
[BSN] Badan Standardisasi Nasional. 2014. SNI 37192014 Minuman Sari Buah. Jakarta: Badan Standardisasi Nasional.

[BSN] Badan Standardisasi Nasional. 2006. SNI 012346-2006 Petunjuk Pengujian Organoleptik dan atau Sensori. Jakarta: Badan Standardisasi Nasional.

[BSN] Badan Standardisasi Nasional. 2000. SNI 066441-2000. Metode Pengujian Viskositas Aspal Minyak Dengan Alat Brookfield Termosel. Jakarta: Badan Standardisasi Nasional.

Farikha IN, Anam C, Widowati E. 2013. Pengaruh jenis dan konsentrasi bahan penstabil alami terhadap karakteristik fisikokimia sari buah naga merah (Hylocereus Polyrhizus) selama penyimpanan. J Teknologi Hasil Pertanian 2(1): 30-38.

[FSSAI] Food Safety and Standards Authority of India. 2012. Manual of Methods of Analysis of Foods. New Delhi (IN): Food Safety and Standards Authorityof
India, Ministry of Health and Family Welfare Government of India.

Iswari K, Harnel, Afdi E, Azman FA, Aswardi. 2006. Kajian Teknologi Pengolahan Manggis Mendukung Agribisnis Manggis di Sumbar. Laporan Hasil Penelitian BPTP Sumbar, T. A.

Pedraza-Chaverri J., Cardenas-Rodriguez N, OrozcoIbarra M, Perez-Rojas JM. 2008. Medicinal properties of mangosteen (Garcinia Mangostana). Food Chem Toxicol 46(10): 3227-39. DOI: 10.1016/j. fct.2008.07.024.

Suvarnakuta P, Chaweerungrat C, Devahastin S. 2011. Effects of drying methods on assay and antioxidant activity of xanthones in mangosteen rind. Int J Food Chem 125(1): 240-247. DOI: 10.1016/j.foodchem. 2010.09.015.

JMP-02-20-02-Naskah diterima untuk ditelaah pada 23 Maret 2020. Revisi makalah disetujui untuk dipublikasi pada 20 April 2020. Versi Online: http://journal.ipb.ac.id/index.php/jmpi 